\title{
Rancang Bangun Aplikasi Pengenalan Rukun Islam Sebagai Media Pembelajaran Menggunakan Teknologi Augmented Reality
}

\author{
Asri Mulyani ${ }^{1}$, Dede Kurniadi ${ }^{2}$, Mahendra Akbar Musadad ${ }^{3}$ \\ Jurnal Algoritma \\ Sekolah Tinggi Teknologi Garut \\ Jl. Mayor Syamsu No. 1 Jayaraga Garut 44151 Indonesia \\ Email : jurnal@itg.ac.id \\ 1'asrimulyani@itg.ac.id \\ 22dede.kurniadi@itg.ac.id \\ 31706070@itg.ac.id
}

\begin{abstract}
Abstrak - Poin utama dari ajaran Islam adalah rukun Islam dan juga merupakan pendoman seorang muslim seperti mengucapkan syahadat, sholat, zakat, puasa, dan naik haji. Pembelajaran mengenai rukun Islam disekolah sering kali disampaikan melalui buku yang terkadang membuat menimbulkan efek bosan untuk menambah minat belajar pada anak disaat kegiatan pembelajaran tidak perbolehkan melakukan tatap muka dikarenakan situasi pandemi covid-19, maka dari itu pembelajaran tersebut dikemas lebih menarik dengan memasukan unsur multimedia. Penelitian ini bertujuan untuk membuat aplikasi pengenalan rukun Islam menggunakan augmented reality yang menjadi variasi. manfaat dari penelitian ini yaitu dapat dijadikan media pembelajaran yang menarik minat anak dalam mempelajari rukun Islam khususnya bacaan dan gerakan sholat dan sebagai alat bantu untuk pengajar dalam menyampaikan pembelajaran tentang rukun Islam. Pembuatan aplikasi ini menggunakan metodologi Research and Development dengan tahapan analisis, pengumpulan data, perancangan desain, implementasi desain, pengujian, validasi ahli, revisi, uji kelayakan, perbaikan media dan produk. Hasil dari penelitian ini berupa aplikasi pengenalan rukun Islam sebagai media pembelajaran menggunakan augmented reality dengan metode marker-based untuk memunculkan objek dan algoritma Speeded Up Robust Features menggunakan platform android untuk mengoprasikannya.
\end{abstract}

Kata Kunci - Augmented Reality; Rukun Islam; Media Pembelajaran; Research and Development.

\section{PENDAHULUAN}

Pendidikan agama Islam merupakan upaya pembentukan anak yang merupakan tanggung jawab bersama untuk mengenalkan ajaran agama Islam dalam mengerti dan menerapkan ajarannya dalam kehidupan sehari-hari yang berakar pada kitab suci Al-Quran dan Al-Hadist khususnya [1]. Terdapat lima poin utama dalam agama Islam yang disebut dengan rukun Islam yang berisi mengucapkan syahadat, sholat, zakat, puasa, dan naik haji bagin yang mampu. Kelima poin ini dapat ditanamkan atau diajarkan kepada anak-anak agar mereka mampu mengingat dan mengertia apa itu rukun Islam dan cara mengamalkannya[2]. Biasanya disekolah atau taman pendidikan saja anak-anak mendapatkan pembelajaran rukun Islam. Dengan kemajuan teknologi yang sangat pesat dalam kehidupan manusia tidak terkecuali dalam bidang pendidikan, dalam bidang pendidikan semakin mudah dalam menyampaikan ilmu pengetahuan tanpa harus bertemu secara langsung [3]. Apalagi dalam situasi pandemic covid-19 berdampak signifikan terhadap berbagai sektor dan pendidikan salah satunya dan salah satu dampaknya adalah dimana sekolah tidak diperbolehkan melakukan kegiatan pembelajaran secara tatap muka [4]. Dengan masalah tersebut memerlukan sebuah media pembelajaran yang menarik minat belajar 
pada anak karena pada umunya pembelajaran menggunakan media buku yang kurang menarik minat anak dan cenderung membosankan, maka dari itu pembelajaran tersebut dikemas lebih menarik dengan memasukan unsur multimedia. Multimedia merupakan gabungan antara teks, gambar, animasi, audio dan video yang bisa digunakan untuk melakukan komunikasi, interaksi dan navigasi dengan menambahkan alat bantu (tools) dan koneksi (link) sehingga menjadi satu kesatuan[5]. Menambahkan fitur Augmented Reality untuk mengemas menjadi multimedia yang menyenangkan, sedangkan teknologi "augmented reality penggabungan benda maya dan benda nyata ke dalam lingkungan nyata dalam waktu yang sama untuk benda maya tersebut bisa dalam bentuk dua dimensi atau dalam bentuk tiga dimensi"[6]. Dengan algoritma Speeded Up Robust Features atau lebih dikenal SURF adalah sebuah kemampuan deteksi citra yang cepat dan mendeskripsikan citra yang terdeteksi secara unik untuk mendeteksi marker sebagai pola yang akan dideteksi atau disebut metode marker based [7].

Adapun beberapa penelitian sebelumnya mengenai media pembelajaran dengan multimedia ataupun implemenrasi teknologi augmented reality yang dipadukan dengan multimedia diantaranya yang pertama dengan judul "Rancang Bangun Aplikasi Pengenalan Dasar Bahasa Arab Sebagai Media Pembelajaran Berbasis Android", media pemberlajaran ini mengenalkan dasar bahasa arab menggunakan animasi, teks, gambar dan suara dalam menyampaikan materi dan menggunakan platform android [8]. Penelitian kedua yaitu "Aplikasi Edukasi Rukun Islam Untuk Anak dengan Pendekatan Multimedia Development Life Cycle", penelitian ini mengenai pengenalan dasar Rukun Islam yang memiliki lima poin utama dan ditamabah dengan adanya gerakan shalat dalam bentuk animasi dua dimensi dan setiap bacaan shalat dalam bentuk audio atau suara [9]. Penelitian ketiga yaitu "Pengembangan Aplikasi Wudhu Dan Shalat Untuk Anak Menggunakan Sistem Multimedia", penelitian ini mengenalkan bacaan atau gerakan wudhu dan sholat yang dikemas dengan media pembelajaran yang memasukan unsur multimedia dengan platform android [10].Penelitian keempat yaitu "Perancangan Media Interaktif Rumus Bangun Ruang Menggunakan Teknologi Augmented Reality Berbasis Android", penelitian ini membahas bagaimana rumus bangun ruang dikemas kedalam media pembelajaran menarik dan terdapat fitur Augmented Reality yang dapat menampilkan bangun ruang 3D setelah memindai marker [11]. Peneliatan kelima yaitu "Media Pembelajaran Pengenalan Komponen Komputer Berbasis Multimedia dengan Pendekatan Metodologi (R\&D)", media pembelajaran ini menggunakan metodologi R\&D mengenalkan komponen komputer yang memiliki unsur multimedia dimana didalamnya terdapat beberapa game edukasi dan juga tutorial menganai komponen komputer tersebut [12].

Adapun tujuan dari penelitian ini membangun sebuah media pembelajaran dimana dari penelitian yang sudah disampaikan terdapat penelitian mengenai rukun Islam namun hanya menggunakan unsur multimedia saja dan belum memadukan antara media pembelajaran multimedia dengan teknologi augmented reality ini diharapkan bisa meningkatkan daya tarik anak dalam mengenal rukun Islam, karena dengan adanya media pembelajaran ini anak dapat mengenal rukun Islam lebih dalam lagi.

\section{METODOLOGI}

Metodologi penelitian menggunakan Research and Development dalam mencapai tujuan dibuatlah Work Breakdown Structure (WBS) untuk setiap pekerjaan supaya sistematis dalam penyelesaiannya seperti yang ada pada Gambar 1. 


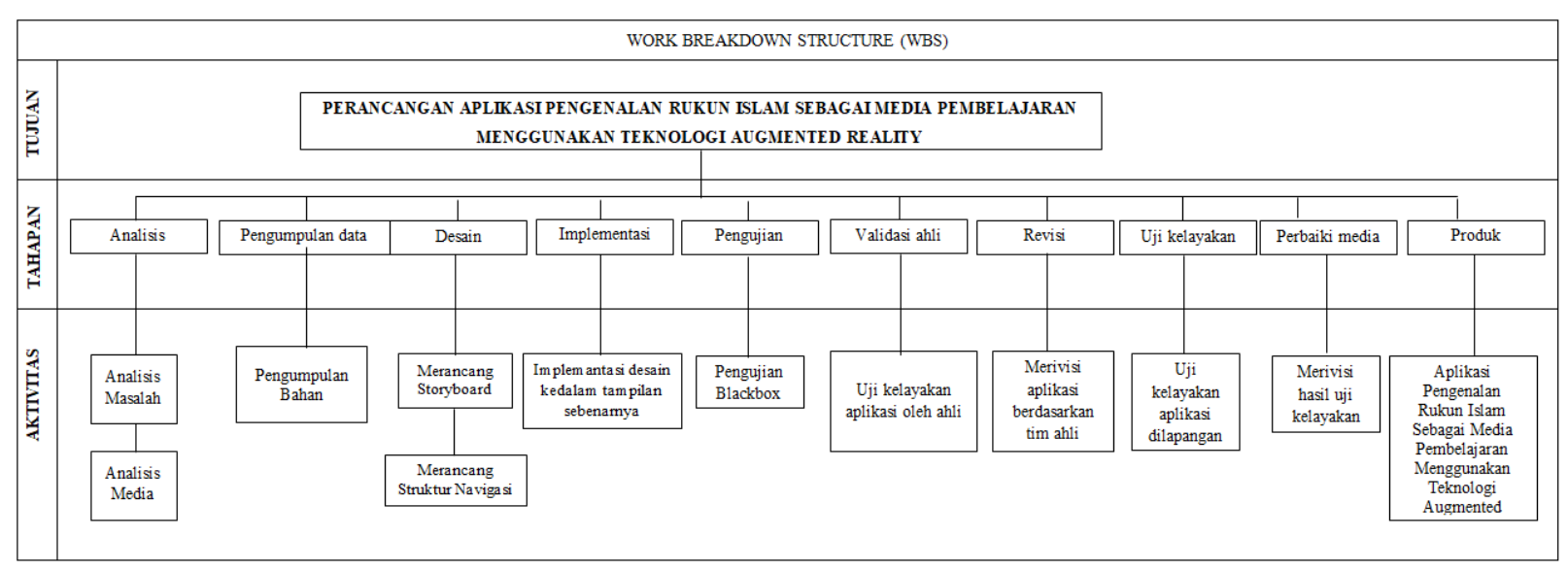

Gambar 1: Work Breakdown Structure

Berikut merupakan pengertian yang ada pada gambar diagram Work Breakdown Structure (WBS) pada Gambar 1:

\section{Analisis}

Dalam analisis ini meninjau kebutuhan yang diperlukan dengan mengumpulkan semua informasi mengenai rukun Islam dan kebutuhan lain untuk menunjang pembuatan aplikasi yang berbentuk media pembelajaran. Dalam tahap ini memiliki dua tahapan yaitu:

a. Analisis masalah

Analisis masalah adalah meneliti masalah yang muncul dalam penyajian data dilapangan dan mencari kemungkinan masalah tersebut dapat diatasi dan dipilih kemungkinan paling besar untuk menyelesaikan masalah tersebut.

b. Analisis media

Analisis media merupakan tahap dimana menentukan bahan-bahan yang diperlukan untuk menunjang dalam pembuatan aplikasi.

\section{Pengumpulan data}

Untuk tahapan ini aktivitas yang dilakukan adalah pengumpulan bahan yang dibutuhkan aplikasi seperti audio, teks, gambar, dan animasi yang telah ditentukan pada tahap sebelumnya, pengumpulan ini tidak harus menggunakan bahan yang sudah ada tapi ada juga yang harus dibuat dari awal menggunakan software.

\section{Perancangan desain}

Pada tahap perancangan ini merupakan pembuatan gambaran keseluruhan aplikasi dalam sistem ataupun antarmuka pada aplikasi yang akan dibuat. Supaya mudah diterjemahkan kedalam bentuk nyata maka diperlukan sketsa desain tampilan layar keseluruhan dan desain tersebut dibuat dalam storyboard serta struktur navigasi.

\section{Implementasi desain}

Pada tahap ini merupakan tampilan sebenarnya hasil dari penerjemahan perancangan desain, setelah kebutuhannya dan rancangannya terpenuhi tahapan implementasi desain bisa dilakukan, dalam melakukan implementasi atau menerjemahkan desain untuk membuat AR baik berupa gambar maupun teks dengan program unity $3 \mathrm{~d}$. 


\section{Pengujian}

Pada tahap ini aplikasi akan diperiksa dan diuji dalam beberapa tahap seperti pada bagian navigasi dalam kesesuaian dengan perintah, apakah navigasi bias di akses, dan melakukan pemeriksaan dengan pendekatan blackbox tasting. Dengan pengujian metode ini ditemukan masalah apakah semua fungsi berjalan sesuai dengan persyaratan yang ditentukan.

\section{Validasi Ahli}

Pada tahap ini diperlukan menacari tenaga ahli untuk melakukan pengujian yang meliputi tombol navigasi, kesalahan navigasi, materi yang tidak sesuai, dan fitur-fitur yang ada dalam aplikasi.

\section{Revisi}

Tahap ini dilakukan setelah tahap validasi ahli selesai, selanjutnya aplikasi direvisi berdasarkan masukan dan saran dari tenaga ahli. Jika yang direvisi telah melakukan validasi kembali maka aplikasi siap untuk diimplementasikan di lapangan.

\section{Uji Kelayakan}

Tahapan ini dilakukan setelah direvisi oleh tenaga ahli dan melakukan uji coba dilapangan kepada para pengguna dan pengguna akan memberikan tanggapan terhadap aplikasi tersebut.

\section{Perbaikan Media}

Dalam tahapan ini merupakan perbaikan media dari hasil responden yang berupa pendapat mereka mengenai aplikasi ini yang telah dilakukan uji coba pada tahap sebelumnya dan akan menjadi masukan untuk penelitian selanjutnya apabila tidak memungkinkan dilakukan perbaikan.

\section{Produk}

Pada tahap ini merupakan mengeluarkan produk yang telah dihasilkan setelah melewatu beberapa tahapan yaitu aplikasi pengenalan rukun Islam sebagai media pembelajaran menggunakan teknologi augmented reality sebagai jawaban dari permasalahan.

\section{HASIL DAN PEMBAHASAN}

\section{A. Hasil Penelitian}

Analisis masalah yang sudah disampaikan sebelumnya yaitu kurangnya variasi dalam pembelajaran dan belum terdapat fitur Augmented Reality pada penelitian sebelumnya yang dimasukan pada rujukan penelitian. Berdasarkan masalah yang disampaikan maka dari itu dibuatlah aplikasi media pembelajaran pengenalan rukun Islam menggunakan teknologi augmented reality agar menjadi variasi dalam proses pembelajaran. Dalam menyampaikan materi menggunakan teknologi augmented reality dalam aplikasi media pembelajaran ini berisi gerakan sholat dan menampilkan kabah 3D pada materi haji. Untuk mencapai tujuan tersebut penelitian ini memiliki yaitu "analisis kebutuhan, pengumpulan data, desain, implementasi, pengujian, validasi ahli, revisi, uji kelayakan, perbaikan media, dan produk" yang terkandung pada metodologi Research and Development [13]. 


\section{Analisis}

Dalam tahapan ini akan dilakukan analisis kebutuhan sesuai keperluan aplikasi yaitu Kumpulkan informasi tentang material dan material yang mendukung pembuatan Program aplikasi seperti analisis masalah dan analisis media.

a. Analisis Masalah

Analisis masalah adalah mencari permasalahan yang sering muncul dalam penyajian data di lapangan dan mengidentifikasi hal yang memungkinkan dapat dipakai dalam mengatasi masalah yang ditemukan. Jadi hal pertama adalah melakukan studi literatur pada sebuah buku dengan maksud untuk melihat materi pendukung penyusunan aplikasi, selanjutnya mengamati beberapa sekolah di Kabupaten Garut Tentang media pembelajaran yang sering digunakan dalam pembelajaran rukun Islam dengan melakukan wawancara dan observasi kepada pengajar dalam penyampaian materi.

b. Analisis Media

Analisis media merupakan tahap mengidentifikasi atau menentukan bahan yang mendukung pembuatan aplikasi berupa hardware, software, gambar, model 3d dan suara, namun semua bahan tidak selalu menggunkan yang sudah ada dan harus dibuat melalui software lain, berikut merupakan tabel dari software yang akan digunakan dalama pembuatan aplikasi :

Tabel 1: Software Pendukung

\begin{tabular}{|c|l|l|}
\hline No & \multicolumn{1}{|c|}{ Software } & \multicolumn{1}{c|}{ Keterangan } \\
\hline 1 & Blender 3D & Pembuatan bahan atau data dalam bentuk model dan animasi 3 dimensi. \\
\hline 2 & Adobe Illustrator CC & $\begin{array}{l}\text { Pembuatan bahan atau data dalam bentuk model, tombol, dan background } \\
\text { dalam bentuk 2 dimensi. }\end{array}$ \\
\hline 3 & Adobe Audition CC & $\begin{array}{l}\text { Pengolahan data suara yang diperlukan untuk backsound dan Suara objek } \\
\text { dengan ekstensi mp3. }\end{array}$ \\
4 & Unity 2017 & $\begin{array}{l}\text { Pembuatan aplikasi dan menggabungkan objek-objek yang dibutuhkan. } \\
\text { Untuk membantu pembuatan aplikasi dalam perangkat } \text { mobile. }\end{array}$ \\
\hline 5 & SDK Vuforia & \multicolumn{2}{|c|}{} \\
\hline
\end{tabular}

\section{Pengumpulan Data}

Pengumpulan data merupakan tahap mengumpulkan data yang telah ditentukan pada tahap sebelumnya apa saja yang dibutuhkan dalam pembuatan aplikasi, berikut merupakan data yang dikumpulkan:

\section{a. Data Gambar}

Data yang dikumpulkan berupa gambar yang digunakan untuk background, tombol, marker, dan objek dengan dua jenis 2D dan 3D terdiri dari ektensi png, jpg, dan fbx yang dibuat dengan software Adobe Illustrator untuk jenis 2D dan Blender untuk jenis 3D.
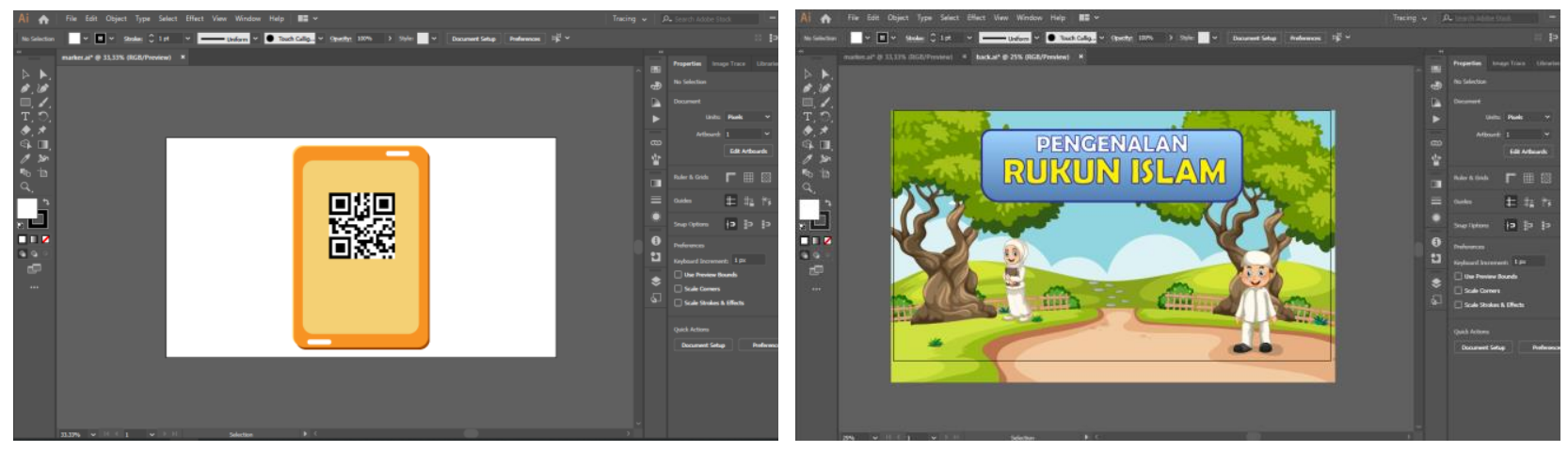

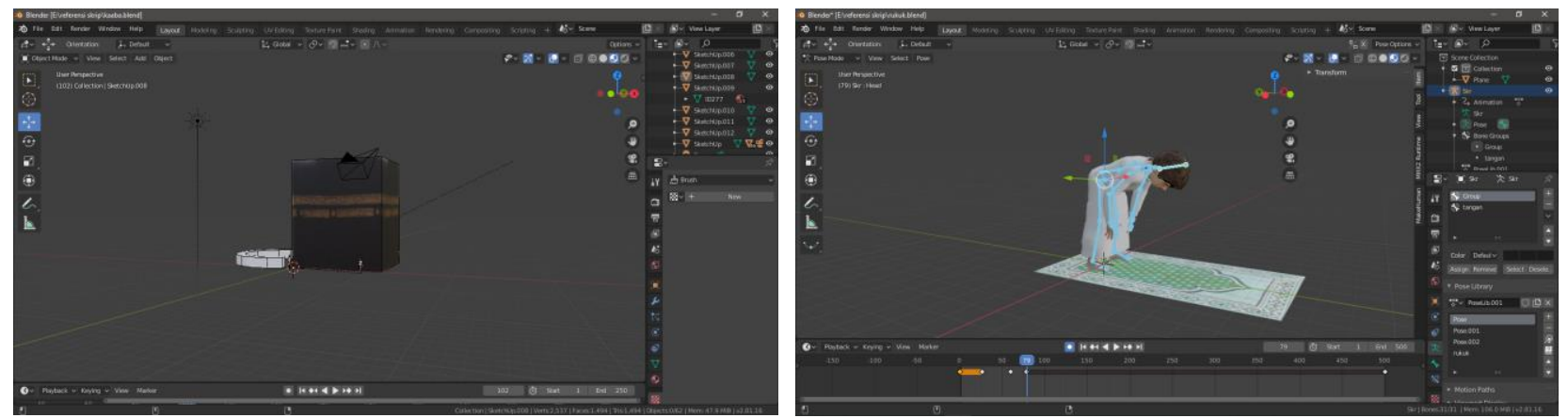

Gambar 2: Pembuatan Data Gambar

b. Data Teks

Data yang dikumpulkan materi sesuai kebutuhan dan apapun yang berbentuk teks dalam jenis huruf Arial Bold, Jinggle bells, Myriad Pro yang bisa langsung dimasukan ke Unity.

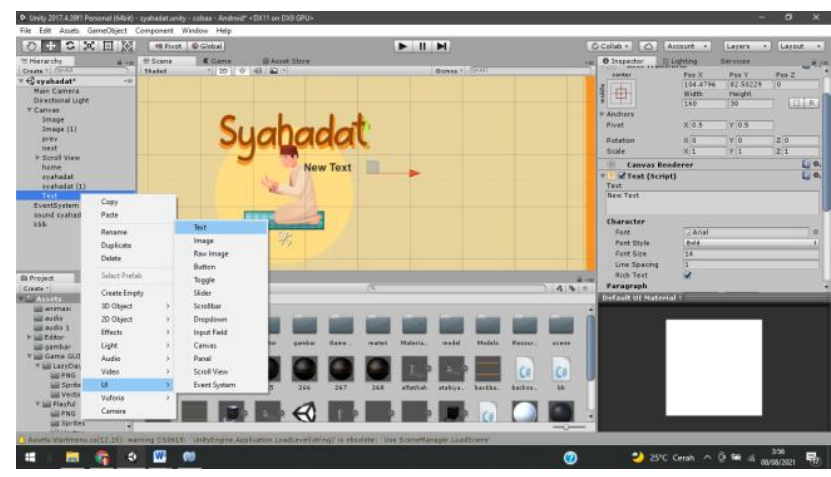

Gambar 3: Pengolahan Data Teks

c. Data Suara

Data yang dikumpulkan berupa suara yang diperlukan untuk backsound dan Suara objek dengan ekstensi mp3 menggunakan Adobe Audition CC.

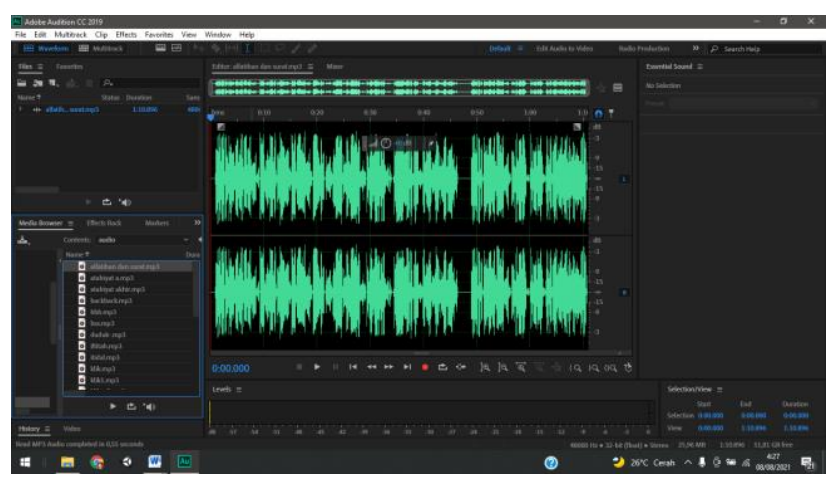

Gambar 4: Pengolahan Data Suara

\section{Perancangan Desain}

Tahap desain merupakan rancangan atau gambaran aplikasi yang akan dibuat secara keseluruhan yang dalam tahapan ini akan diperlukan sketsa untuk mempermudah dalam pembuatan aplikasi. Sketsa tersebut dalam bentuk storyboard dan dalam struktur navigasi untuk mempermudah penerjemahaan kedalam bentuk nyata atau kedalam bentuk sebenarnya. 


\section{a. Storyboard}

Tabel 2: Storyboard

\begin{tabular}{|c|c|}
\hline Scene & Keterangan \\
\hline Scene 1 & Halaman ini menampilkan animasi loading \\
\hline Scene 2 & $\begin{array}{l}\text { Halaman ini menampilkan nama dari aplikasi beseta menu play, sound, info, email, dan } \\
\text { exit }\end{array}$ \\
\hline Scene 3 & $\begin{array}{l}\text { Halaman ini menampilkan } 5 \text { tombol menu materi yaitu syahadat, sholat, zakat, puasa dan } \\
\text { haji }\end{array}$ \\
\hline Scene 4 & $\begin{array}{l}\text { Halaman ini berisi materi mengenai syahadat yang ditampilkan melalui teks dan ilustrasi } \\
\text { gambar }\end{array}$ \\
\hline Scene 5 & $\begin{array}{l}\text { Halaman ini berisi materi mengenai sholat yang ditampilkan melalui teks dan ilustrasi } \\
\text { gambar }\end{array}$ \\
\hline Scene 6 & $\begin{array}{l}\text { Halaman ini berisi materi mengenai zakat yang ditampilkan melalui teks dan ilustrasi } \\
\text { gambar }\end{array}$ \\
\hline Scene 7 & $\begin{array}{l}\text { Halaman ini berisi materi mengenai puasa yang ditampilkan melalui teks dan ilustrasi } \\
\text { gambar }\end{array}$ \\
\hline Scene 8 & Halaman ini berisi materi mengenai haji yang ditampilkan melalui teks dan ilustrasi gambar \\
\hline Scene 9 & $\begin{array}{l}\text { Halaman ini membuka kamera yang berfungsi membaca marker yang didalamnya memiliki } \\
\text { barcode yang berbeda yang sudah dimasukan kedalam database vuforia, sehingga ketika } \\
\text { marker di scan maka akan keluar objek 3D gerakan sholat beserta suara sesuai marker } \\
\text { tersebut }\end{array}$ \\
\hline Scene 10 & $\begin{array}{l}\text { Halaman ini membuka kamera yang berfungsi membaca marker yang didalamnya memiliki } \\
\text { barcode yang berbeda yang sudah dimasukan kedalam database vuforia, sehingga ketika } \\
\text { marker di scan maka akan keluar objek 3D kabah }\end{array}$ \\
\hline
\end{tabular}

b. Struktur Navigasi

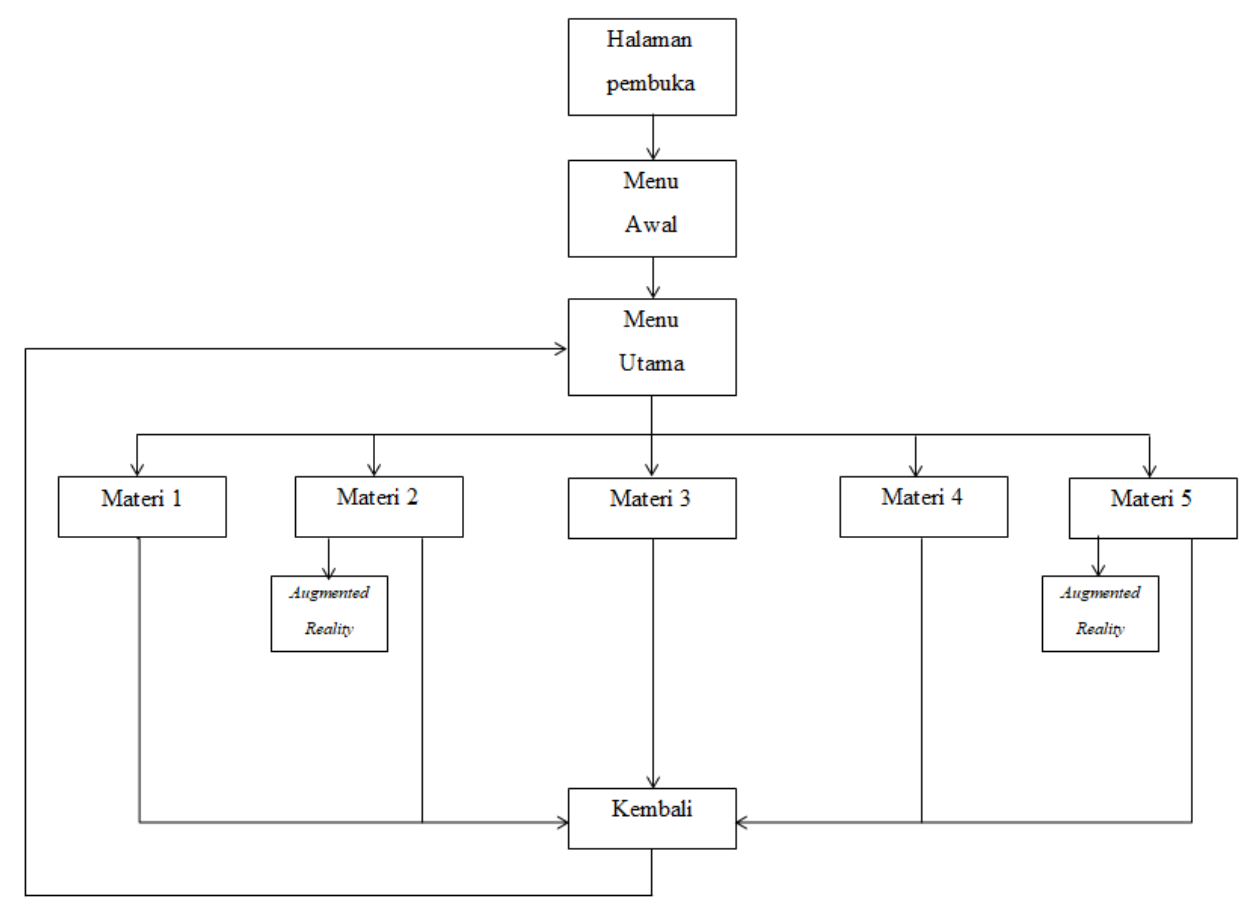

Gambar 5: Perancangan Struktur Navigasi 


\section{Implementasi Desain}

Pada tahapan implementasi desain merupakan proses penerjemahan ke tampilan aplikasi yang sebenarnya dari desain dan dapat dilakukan setelah kebutuhan data dan rancangan terpenuhi. Untuk menerjemahkan desain tersebut menggunakan program Blender untuk membuat model 3D, Adobe Illustrator untuk pembuatan gambar, dan Unity untuk menyatukan atau membuat AR dan aplikasi.
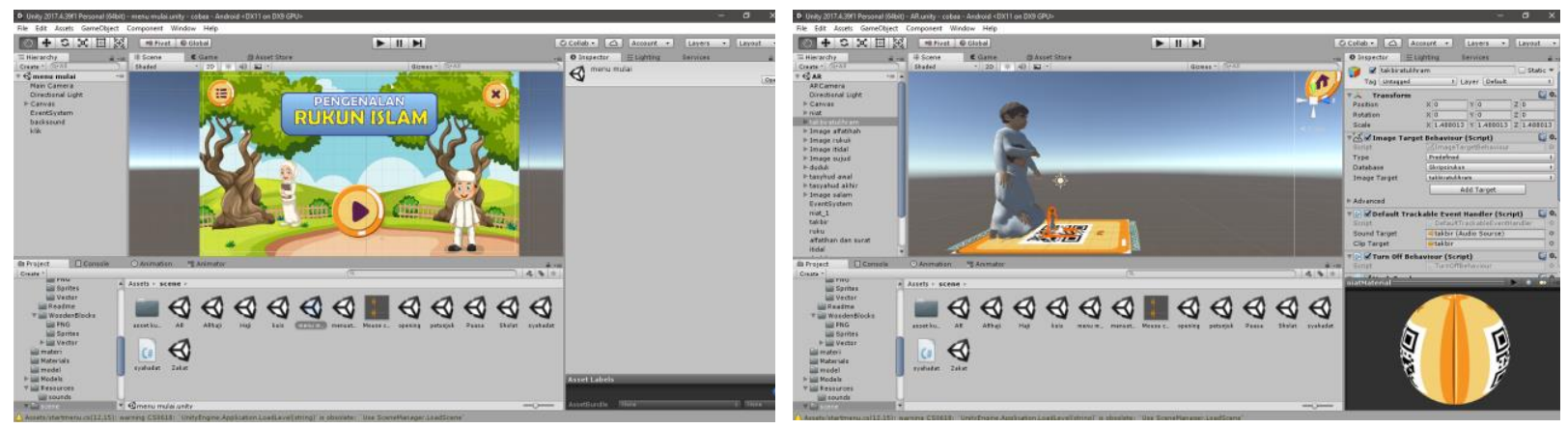

Gambar 6: Pembuatan Aplikasi

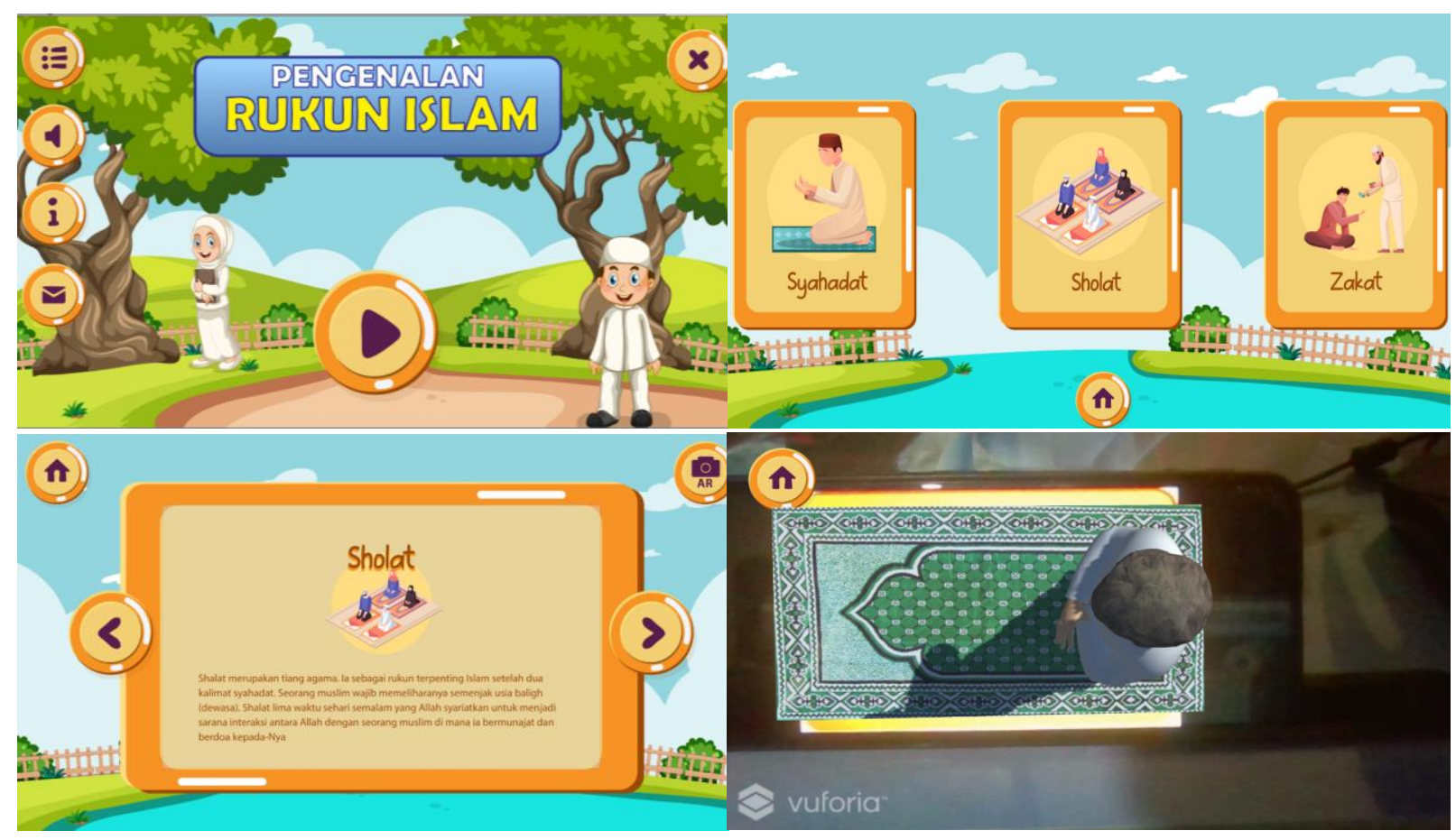

Gambar 7: Tampilan Aplikasi Pengenalan Rukun Islam

\section{Pengujian}

Dalam tahap pengujian ini menggunakan pengujian fungsional atau lebih dikenal dengan black box testing dimana merupakan pengujian atau pemeriksaan perangkat lunak yang dilakukan tanpa harus mengetahui struktur kode dan aplikasi. 
Tabel 3: Pengujian Blackbox

\begin{tabular}{|c|l|l|l|}
\hline No & \multicolumn{1}{|c|}{ Kelas Uji } & \multicolumn{1}{|c|}{ Butir Uji } & Hasil Uji \\
\hline 1 & Instalasi aplikasi & Pemasangan aplikasi pada perangkat smartphone & Berhasil \\
\hline 2 & Halaman pembuka & Tampil dan animasi berjalan pada layar & Berhasil \\
\hline 3 & Halaman menu awal & $\begin{array}{l}\text { Tampil menu awal aplikasi } \\
\text { Muncul suara backsound } \\
\text { Tampil pop up mengenai pembuat aplikasi }\end{array}$ & $\begin{array}{c}\text { Berhasil } \\
\text { Berhasil } \\
\text { Berhasil }\end{array}$ \\
\hline 4 & Halaman menu utama & Tampil menu utama aplikasi & Berhasil \\
\hline 5 & Halaman materi 1 & Tampil materi tentang syahadat & Berhasil \\
\hline 6 & Halaman materi 2 & Tampil materi tentang sholat & Berhasil \\
\hline 7 & Halaman materi 3 & Tampil materi tentang zakat & Berhasil \\
\hline 8 & Halaman materi 4 & Tampil materi tentang puasa & Berhasil \\
\hline 9 & Halaman materi 5 & Tampil materi tentang haji & Berhasil \\
\hline 10 & Halaman AR kamera 1 & $\begin{array}{l}\text { Memunculkan kamera } \\
\text { Memendai marker }\end{array}$ & Berhasil \\
& & $\begin{array}{l}\text { Menampilkan objek gerakan sholat } \\
\text { Memunculkan suara dari gerakan sholat }\end{array}$ & Berhasil \\
& & $\begin{array}{l}\text { Memunculkan kamera } \\
\text { Memendai marker }\end{array}$ \\
\hline 11 & Halaman AR kamera 2 & Berhasil \\
& & Menampilkan objek kabah & Berhasil \\
Berhasil
\end{tabular}

\section{Validasi Ahli}

Dalam tahapan validasi ini dilakukan oleh seorang ahli yang berkompeten dalam bidang multimedia yaitu seorang guru multimedia untuk pengujian yang meliputi navigasi berjalan baik atau tidak, kesesuaian perintah, pemeriksaan fitur aplikasi dan kesesuaian materi.

Tabel 4 Validasi Ahli

\begin{tabular}{|c|c|c|c|c|c|c|c|}
\hline \multirow{2}{*}{ No. } & \multirow{2}{*}{ Indikator Validasi } & \multirow{2}{*}{ Deskripsi } & \multicolumn{5}{|c|}{ Skala Nilai } \\
\hline & & & 1 & 2 & 3 & 4 & 5 \\
\hline \multirow[t]{4}{*}{1.} & \multirow[t]{4}{*}{ Tampilan Umum } & a. Desain aplikasi sesuai dengan fungsi & & & & & $\sqrt{ }$ \\
\hline & & b. Desain media menarik & & & & & $\sqrt{ }$ \\
\hline & & c. Augmented Reality berfungsi & & & & $\sqrt{ }$ & \\
\hline & & d. Dapat dijalankan di smartphone lain & & & & $\sqrt{ }$ & \\
\hline \multirow[t]{2}{*}{2.} & \multirow[t]{2}{*}{ Tampilan Khusus } & a. Komposisi warna menarik & & & & & $\sqrt{ }$ \\
\hline & & b. Tombol yang sesuai dengan konsep aplikasi & & & $\sqrt{ }$ & & \\
\hline \multirow[t]{5}{*}{3.} & \multirow[t]{5}{*}{ Penyajian Aplikasi } & a. Tampilan aplikasi menarik dan mudah & & & & $\sqrt{ }$ & \\
\hline & & b. Penyajian materi menarik & & & & $\sqrt{ }$ & \\
\hline & & c. Tampilan aplikasi cukup detail & & & & & $\sqrt{ }$ \\
\hline & & d. Tampilan tersusun rapi dan teratur & & & & $\sqrt{ }$ & \\
\hline & & e. Suara sesuai dengan objek & & & & $\sqrt{ }$ & \\
\hline & Rata-rata & & 4,2 & & & & \\
\hline
\end{tabular}




\section{Revisi}

Dalam tahapan ini dilakukan revisi dari hasil masukan dari validasi ahli yang sebelumnya dilakukan validasi oleh ahli yang berkompeten dalam bidang multimedia dan setelah revisi memenuhi syarat maka selanjutnya aplikasi ini siap di implementasi ke lapangan.

\section{Uji Kelayakan}

Dalama tahapan ini aplikasi akan di uji coba dilapangan setelah sebelumnya dinyatakan layak oleh ahli, uji kelayakan ini melibatkan 10 orang pengajar dan 10 orang siswa untuk diminta memberikan tanggapan untuk aplikasi dengan 8 pertanyaan dan untuk hasil kuisioner sebagai berikut :

a. Hasil kuisioner pengajar/guru

$\begin{array}{lll}\text { TP } & \text { : Total Pemilih } & \text { JP : Jumlah Pertanyaan } \\ \text { TN } & \text { : Total Nilai } & \text { JU : Jumlah Penguji } \\ \text { ST } & \text { : Skor Tertinggi } & \text { HA : Hasil Akhir } \\ \text { NT } & \text { : Nilai Tertinggi } & \text { N : Skala Nilai }\end{array}$

Total Nilai $=(\mathrm{TP} \times \mathrm{N})$

$$
\begin{aligned}
& =(56 \times 5)+(16 \times 4)+(8 \times 3)+(0 \times 2)+(0 \times 1) \\
& =280+64+27+0+0 \\
& =371
\end{aligned}
$$

Skor Tertinggi $=(\mathrm{NT} \times \mathrm{JP} \times \mathrm{JU})$

$$
=5 \times 8 \times 10=400
$$

Hasil Akhir $=(\mathrm{TN} / \mathrm{ST} \times 100 \%)$

$$
\begin{aligned}
& =371 / 400 \times 100 \% \\
& =92,75 \%
\end{aligned}
$$

Hasil Akhir yang dipadat dari kuisioner pengajar/guru senilai 92,75\%

b. Hasil kuisioner siswa

$\begin{array}{lll}\text { TP } & \text { : Total Pemilih } & \text { JP : Jumlah Pertanyaan } \\ \text { ST } & \text { : Skor Tertinggi } & \text { HA : Hasil Akhir } \\ \text { TN } & \text { : Total Nilai } & \text { JU : Jumlah Penguji } \\ \text { NT } & \text { : Nilai Tertinggi } & \text { N : Skala Nilai }\end{array}$

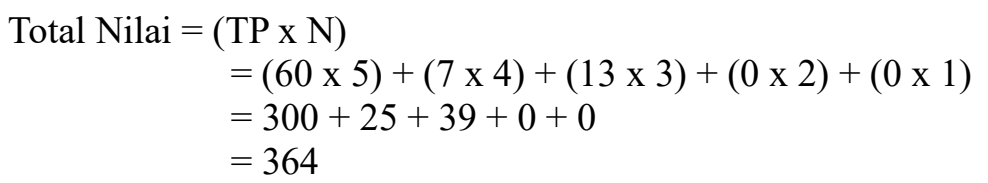

Skor Tertinggi $=(\mathrm{NT} \times \mathrm{JP} \times \mathrm{JU})$

$$
=5 \times 8 \times 10=400
$$

$$
\begin{aligned}
\text { Hasil Akhir }= & (\mathrm{TN} / \mathrm{ST} \times 100 \%) \\
& =364 / 400 \times 100 \% \\
& =91 \%
\end{aligned}
$$

Hasil Akhir yang dipadat dari kuisioner siswa senilai 91\%

Berdasarkan hasil uji kelayakan dilapangan dari dua klasifikasi pengguna untuk responden dari pengajar/guru mendapatkan hasil akhir 92,75\%, dan untuk responden siswa didapatkan hasil akhir $91 \%$. Jadi untuk keseluruhan mendapatkan hasil akhir sebanyak $91,87 \%$ itu artinya aplikasi yang dibuat mendaptakan penilaian sangat baik. 


\section{Perbaikan Media}

Pada tahap ini dilakukan perbaikan media berdasarkan masukan dari responden setelah sebelumnya aplikasi diuji cobakan dilapangan kepada responden dan sehubungan dengan keterbatasan waktu maka tidak memungkinkan melakukan perbaikan dan akan menjadi berupa saran yang berfungsi untuk menjadi masukan untuk peneliti selanjutnya.

\section{Produk}

Pada tahap ini produk telah dihasilkan setelah melalui tahap validasi ahli dan uji kelayakan aplikasi tersebut adalah aplikasi pengenalan rukun Islam sebagai media pembelajaran menggunakan teknologi augmented reality untuk kemudian di simpan dalam hardisk atau google drive.

\section{B. Pembahasan Hasil}

Aplikasi pembelajaran mengenai rukun Islam merupakan hasil dari penelitian ini dibuat dengan software Unity dengan metode marker based dengan algoritma SURF pada Vuforia yang berfungsi inisiasi awal, menangkap pola marker, dan eksekusi marker ditemukan atau tidak ditemukan. Aplikasi pembelajaran ini ditujukan kepada anak berumur 5-7 tahun yang merupakan siswa tamanan kanak-kanak dan sekolah dasar serta pengajar/guru dengan harapan bisa membantu dalam penyampaian materi dengan variasi yang berbeda dengan adanya teknologi augmented reality dalam aplikasi cukup menarik perhatian guru dan minat belajar anak dalam pembelajaran rukun Islam apalagi disituasi pandemi yang mengharuskan anak atau siswa belajar dirumah. Penggunaan metode R\&D dengan sepuluh tahapan dimulai dari analisis kebutuhan sampai ke produk dalam pembuatan aplikasi ini dan memiliki nilai validasi tinggi karena melewati validasi ahli dan uji coba di lapangan.

\section{KESIMPULAN}

Kesimpulan dari pembahasan yang telah diberikan yang berdasarkan hasil adalah sebagai berikut:

1. Aplikasi pengenalan rukun Islam ini dapat dijadikan alternatif atau variasi dalam media pembelajaran rukun Islam yang pada umumnya menggunakan media ajar buku atau media pembelajaran lain yang belum menggunakan augmented reality serta bisa digunakan dimanapun dan kapanpun dikarenakan media pembelajaran ini menggunakan platform android.

2. Aplikasi pengenalan rukun Islam menggunakan augmented reality dalam memperagakan gerakan sholat menggunakan animasi 3D disertai suara bacaan setiap gerakan dan menggambarkan objek kabah dalam bentuk 3D.

Saran untuk meningkatkan kinerja sistem dan agar aplikasi ini terus dikembangkan, seperti:

1. Untuk penelitian selanjutnya diharapakan menaambahan fitur evaluasi dalam aplikasi pengenalan rukun Islam.

2. Tambahan fitur dalam materi pembelajaran zakat dan puasa supaya semua materi memiliki fitur masingmasing.

\section{DAFTAR PUSTAKA}

[1] M. Y. Ahmad and S. Nurjannah, "Hubungan Materi Pembelajaran Pendidikan Agama Islam dengan Kecerdasan Emosional Siswa," Al-Hikmah J. Agama dan Ilmu Pengetah., vol. 13, no. 1, pp. 1-17, 2016, doi: 10.25299/al-hikmah:jaip.2016.vol13(1).1509.

[2] N. Jalil, "Peran Sentra Iman dan Taqwa dalam Menanamkan Keimanan pada Anak Usia Dini," $J$. Pendidik. dan Pemikir. Islam, vol. 6, no. 2, pp. 1-10, 2019.

[3] M. Muhasim, "Pengaruh Tehnologi Digital terhadap Motivasi Belajar Peserta Didik," Palapa, vol. 5, 
no. 2, pp. 53-77, 2017, doi: 10.36088/palapa.v5i2.46.

[4] L. D. Herliandry, Nurhasanah, M. E. Suban, and K. Heru, "Transformasi Media Pembelajaran Pada Masa Pandemi Covid-19," J. Teknol. Pendidik., vol. 22, no. 1, pp. 65-70, 2020, [Online]. Available: http://journal.unj.ac.id/unj/index.php/jtp.

[5] T. Limbong and J. Simarmata, Media dan Multimedia Pembelajaran: Teori \& Praktik. Yayasan Kita Menulis, 2020.

[6] Z. Rawis, V. Tulenan, and B. Sugiarso, "Saidah, M. (2017). Pengaruh Techologi Digital Terhadap Motivasi Belajar peserta Didik. Jurnal Studi Keislaman dan Ilmu Pendidikan," E-Journal Tek. Inform., vol. 13, no. 1, pp. 30-37, 2018.

[7] A. A. A. Ari, "Penerapan Algoritma Surf Pendeteksi Objek Pada Augmented Reality Berbasis Android," JATISI (Jurnal Tek. Inform. dan Sist. Informasi), vol. 6, no. 2, pp. 240-249, 2020, doi: 10.35957/jatisi.v6i2.217.

[8] D. Tresnawati and R. F. Rizqi, "Rancang Bangun Aplikasi Pengenalan Dasar Bahasa Arab Sebagai Media Pembelajaran Berbasis Android," J. Algoritm., vol. 14, no. 2, pp. 314-322, 2017, doi: 10.33364/algoritma/v.14-2.314.

[9] D. Tresnawati, Y. Septiana, and A. Khofidin, "Aplikasi Edukasi Rukun Islam Untuk Anak dengan Pendekatan Multimedia Development Life Cycle," J. Algoritm., vol. 16, no. 2, pp. 166-172, 2020, doi: 10.33364/algoritma/v.16-2.166.

[10] S. Rahayu and P. Denenty, "Pengembangan Aplikasi Wudhu Dan Shalat Untuk Anak Menggunakan Sistem Multimedia," J. Algoritm., vol. 14, no. 2, pp. 606-612, 2017, doi: 10.33364/algoritma/v.142.606.

[11] D. A. Afthori, D. Kurniadi, and A. R. Atmadja, "Perancangan Media Interaktif Rumus Bangun Ruang Menggunakan Teknologi Augmented Reality Berbasis Android," Integr. (Information Tecknology Vocat. Educ., vol. 1, no. 2, pp. 9-13, 2019.

[12] D. D. S. Fatimah, D. Tresnawati, and A. Nugraha, "Media Pembelajaran Pengenalan Komponen Komputer Berbasis Multimedia Dengan Pendekatan Metodologi (R\&D)," J. Algoritm., vol. 16, no. 2, pp. 278-285, 2020, doi: 10.33364/algoritma/v.16-2.278.

[13] Sugiyono, Metode Penelitian Kuantitatif, Kualitatif, dan R\&D. Bandung: CV Alfabeta, 2017. 